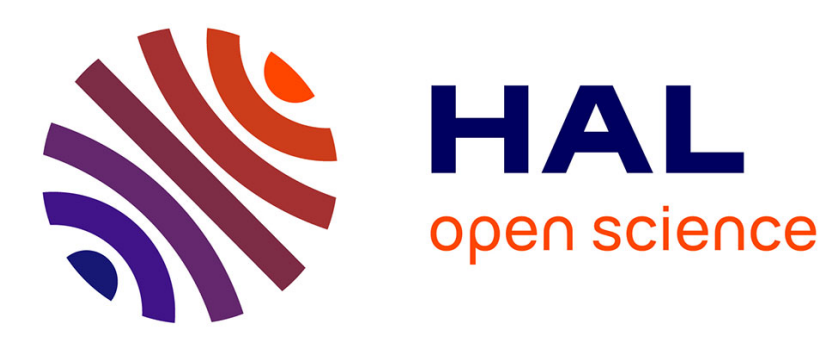

\title{
LASER INDUCED TRANSFORMATION OF THIN AMORPHOUS CrNi FILMS
}

\author{
M. Bîrjega, M. Dinescu, C. Sârbu, M. Chvoika
}

\section{To cite this version:}

M. Bîrjega, M. Dinescu, C. Sârbu, M. Chvoika. LASER INDUCED TRANSFORMATION OF THIN AMORPHOUS CrNi FILMS. Journal de Physique IV Proceedings, 1991, 01 (C7), pp.C7-73-C7-76. 10.1051/jp4:1991716 . jpa-00250836

\section{HAL Id: jpa-00250836 https://hal.science/jpa-00250836}

Submitted on 1 Jan 1991

HAL is a multi-disciplinary open access archive for the deposit and dissemination of scientific research documents, whether they are published or not. The documents may come from teaching and research institutions in France or abroad, or from public or private research centers.
L'archive ouverte pluridisciplinaire HAL, est destinée au dépôt et à la diffusion de documents scientifiques de niveau recherche, publiés ou non, émanant des établissements d'enseignement et de recherche français ou étrangers, des laboratoires publics ou privés. 


\title{
LASER INDUCED TRANSFORMATION OF THIN AMORPHOUS CrNi FILMS
}

\author{
M.I. BÎRJEGA, M. DINESCU, C. SÂRBU and M. CHVOIKA* \\ Institute of Atomic Physics, P.O. Box MG-6 Magurele, R-76900 Bucharest, Romania \\ *Institute of Physics, Na Slovance 2, 180.40, Praha 8, Czechoslovakia
}

\begin{abstract}
TEM and TED are presented on the crystallization and oxidation of the $60 \mathrm{~nm}$ thick amorphous CrNi (5.5:45) films supported on electron microscope copper grids when submitted in air to the action. of a single photodissociation iodine laser $(. \lambda \simeq 1.315 \mu \mathrm{m})$ pulse. The laser could operate in Q-switched regime, with a typical fullwidth half-maximum $\tau_{\text {FWHM }} 5$ $n s$ and a power intensity $I$, of $6.7 \times 10.6 \mathrm{~W} \cdot \mathrm{cm}^{-2}$.
\end{abstract}

\section{Introduction}

The structural and chemical transformation in amorphous CrNi (55:45) and $C_{r}$ thin films supported on EM copper grids induced by air. irradiation with a single-pulse $T E C_{2}$ Iaser $(\lambda=10.6 \mu \mathrm{m} ; \tau=2.5 \mu \mathrm{s}$; $\left.I=0.3 \div 1.2 \times 106 \mathrm{~W} \cdot \mathrm{cm}^{-2}\right)$, a free running ruby 1 aser $(\lambda=0.69 \mu \mathrm{m}$ $\tau=400 \mu \mathrm{s} ; \ldots I=7.5 \times 10^{2} \mathrm{~W} \cdot \mathrm{cm}^{-2} \div 13.7 \mathrm{x} 103 \mathrm{~W} \cdot \mathrm{cm}^{-2}, \mathrm{a}$ Q-switch ruby laser $\left(\lambda=0.69 \mu \mathrm{m} ; \tau=60 \mathrm{~ns}, I=0.7 \times 105 . \mathrm{W} \cdot \mathrm{cm}^{-2} \div 0.9 \mathrm{X} \cdot 10^{6} \mathrm{~W} \cdot \mathrm{cm}^{-2}\right)$, an excimer laser $\left(\lambda=0.308 \mu \mathrm{m} ; \tau=20 \mathrm{~ns} ; \quad I=0.6 \times 105 \mathrm{~W} \cdot \mathrm{cm}^{-2} \div\right.$ $1.2 \times 10^{6} \mathrm{~W} \cdot \mathrm{cm}^{-2}$ ) was previously studied by us [i -5$]$ using TEM and TED. In all the performed experiment we observed that the EM copper grid meshes ( $\phi \simeq 120 \mu \mathrm{m})$, which support the CrNi (55:45) or Cr thin film, channel the incident laser beam so that at mesh level in the irradiated spot $\left[0.5 \times 10^{-2} \mathrm{~cm}^{2} \div 7 \times 10^{-2} \mathrm{~cm}^{2}\right]$ temperature gradients develop from the center of the mesh towards. its borders. Thus at grid mesh level in the irradiated area, a sequence of microstructures could be noticed beginning near the grid mesh with amorphous untransformed CrNi (55:45) or $\mathrm{Cr}$, then fine crystallized CrNi or Cr, with a microstructure similar to that obtained by vacuum annealing treatment [6] or vacuum deposition at higher substrate. temperatures. [7, 8]. Perforation, melting and cracking are characteristic to the centre of the mesh, where the oxidation and crystallization processes attain the highest degree, especially at the Cr thin films $[4,5]$.

\section{Experimental procedure}

Icosahedral amorphous [9] $60 \mathrm{~nm}$ thick CrNi (55:45) films were deposited onto freshly air-cleaved $\mathrm{KCI}$ substrates using a standard $\mathrm{RF}$ sputtering apparatus. Details on the deposition conditions are given in our previous paper [6]. The films were removed from the KCI sub - 
strates by immersion in distilled water and floated of $f$ onto EM copper grids (i.e. networks of circular $120 \mu \mathrm{m}$ diameter holes). These films are referred to as free standing (FS) samples [10].

The irradiation was performed in air, at room temperature, using a Qswitch ( $\left.\tau_{\text {FWHM }}=5 \mathrm{~ns}\right)$, photodissociation iodine laser $(\lambda=1.315 \mu \mathrm{m})$. The laser beam was focused at normal incidence onto the FS, CrNi(55: 45) samples, ensuring a intensity of $6.7 \times 106 \mathrm{~W} \cdot \mathrm{cm}^{-2}$ in the irradiation spot area $\left(0.5 \times 10^{-2} \mathrm{~cm}^{2}\right)$.

The irradiation effects were observed by examination of the free-standing (FS) CrNi (55:45) samples in a TEM 200 CX electron microscope working at $200 \mathrm{kV}$ in the conventional TEM and TED modes.

\section{Results and discussions}

The TEM and TED investigations performed on the photodjssociation iodine laser $\left(\lambda \simeq 1.315 \mu \mathrm{m}\right.$. TWHM $=5$ ns. $\left.I=6.7 \times 10^{6} \mathrm{~W} \cdot \mathrm{cm}^{-2}\right)$ irra diated amorphous CrNi (55:45), Fs thin films have essentially confirmed our previous results $[1-5]$

The Role of EM Copper Grids in the Crystallization Process of the CrNi (5.5:45) Thin Eilms

Despite the large area of the irradiation spot $\left(0.5 \times 10^{-2} \mathrm{~cm}^{2}\right)$ and the uniformity of the incident energy, the effects of the 5 ns single laser pulse are clearly a characteristic of the corresponding area of one mesh $\left(\sim 7.8 \times 10^{3} \mathrm{\mu m}^{2}\right)$ of the EM copper grid. As we can see from the electronmicrographs. (fig. I, low - magnification and enlarged view) like in our previous experiments [I - 5], under the action of the laser irradiation, we observed the formation of four zones with characteristic microstructures denoted by $A, B, C$ and $D$. The perforation, melting or cracking of the CrNi (55:45) thin film (zone A) are induced in the centre of the copper grid mesh. by the heat release into the $60 \mathrm{~nm}$ thick sample and or the stresses produced by their sudden crystallization and oxidation (fig. I).

Surrounding zone. A, there is zone $B$ where the melted superficial layer is rippled with periodicities $\Lambda$ ranging from $0.58 \mu \mathrm{m}$ to $1 \mu \mathrm{m}$. of less extent at low magnification, we find zone $C$ located next to $B$. Electronmicrograph and electrondiffraction patterns from this zone $\left(\mathrm{C}_{1}, \mathrm{C}_{2}\right)$ certify that the temperatures attained are stepwise lower so that, zone $\mathrm{C}_{2}$, marks the beginning of a heterogeneous crystallization by the nucleation of the metastable extended-NiCr ( $f(c)$ crystals. In zone $\mathrm{C}_{1}$ higher temperatures are to be attained because, both the EM and the $E D$ data give evidence that the $\gamma-\mathrm{NiCr}$ crystals are grown in size and also that small crystals of the $\mathrm{Cr}_{3} \mathrm{O}_{4}$ oxide are formed. Zone $\mathrm{D}$ corresponds to the thin film next to the mesh edge that maintains its original structure [6].

As we have mentioned from the beginning the formation of such a microstructure range can only be accounted for by a local laser induced temperature distribution $T(r, t)$. Which is essentially generated by heat losses to the copper grid support. If as a rule, due to the appearance of these thermal gradients between the centre and the mesh edge of the EM copper grid we find the mentioned $A, B, C$ and $D$ microstructures in the irradiated area of the amorphous CrNi(55:45) or Cr thin films independently of the laser parameters and: deposited energy. [1 - 5] some differences can be noticed in the crystallization or oxidation behaviour. So at the lowest intensity $\left(I=1.4 \times 10^{2} \mathrm{~W} \cdot \mathrm{cm}^{-2}\right)$ at the CrNi (5.5:45) one pulse irradiated $(\lambda=0.69 \mu \mathrm{m}, \tau=400 \mu \mathrm{s})$. the first crystallization step (zone. $C_{2}$ ) is the $\alpha$-CrNi extended solid solution [I] obtained by a polymorphous type of crystallization. Chaplanov 


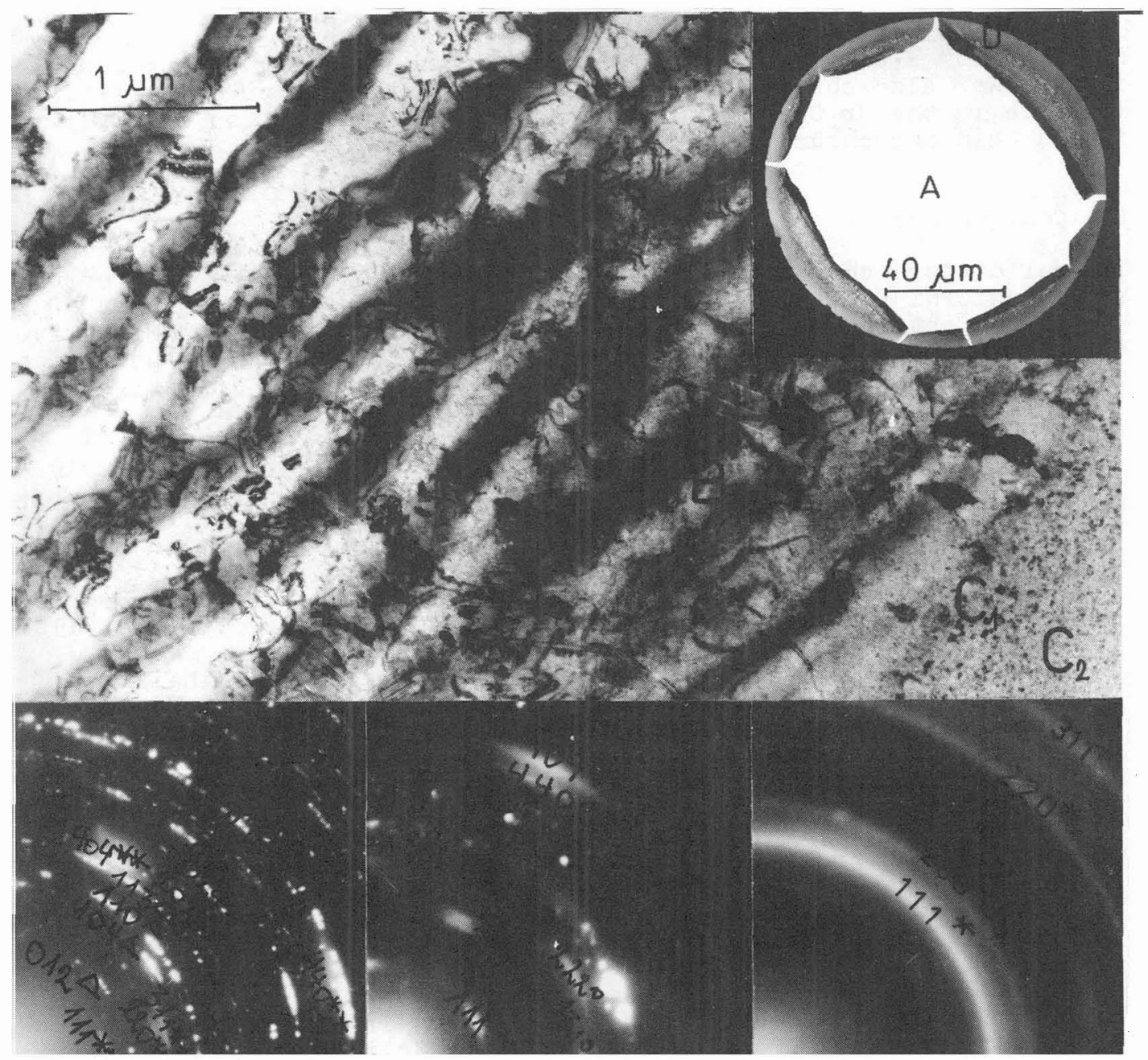

Fig. 1. Electronmicrographs of one EM copper grid mesh from the laser irradiated $(\lambda=1.315 \mu \mathrm{m}$; $\tau$ FWHM $=5 \mathrm{~ns}$; $I=6.7 \times 10^{6}$ W. $\left.\mathrm{cm}^{-2}\right)$ area $\left(0.5 \times 10^{-2} \mathrm{~cm} 2\right)$ of the (FS). CrNi ( $55: 45$ ) film and their corresponding enlarged view. The four $A, B, C_{1}, C_{2}[1-5]$ zones are marked on the electronmicrograph and the corresponding electrondiffraction patterms. Indices bikl of the indexed phases :

(*) $\gamma$-NiCr [ASTM-4-0850]; (o) $\mathrm{Cr}_{3} \mathrm{O} 4$ [ASTM-12-559]; (A) $\alpha-\mathrm{Cr}_{2} \mathrm{O}_{3}$ [ASTM-6-0505]; (**) $\mathrm{NiCr}_{2} \mathrm{O}_{4}$ [ASTM-4-0763]. Ripple periodicites $\Lambda$ ranging from $0.58 \mu \mathrm{m}$ to $1 \mu \mathrm{m}$. 
and Tochitsky. [12] observed in the case of one pulse irradiated polycrystalline textured 100 to $500 \mathrm{~nm}$ thick $\mathrm{Cr}$ film that the formation of the $\mathrm{Cr}_{3} \mathrm{O}$ oxides is favored both by an increase in the power density from $6 \times 104 \mathrm{~W} \cdot \mathrm{cm}^{-2}$ to $1.3 \times 105 \mathrm{~W} \cdot \mathrm{cm}^{-2}$ and by using vacuum instead. of air. We also observed, a laser power density and pulse duration dependence in the $\mathrm{Cr}_{3} \mathrm{O}_{4}$ oxide formation ard crystallization in air irradiated thin amorphous $\mathrm{Cr}$ and $\mathrm{CrNi}(55: 45)$ films $[4,5]$.

\section{Conclusions}

Lateral differences in the crystallization and oxidation of $60 \mathrm{~nm}$ thick amorphous. CrNi (5:5:45) films supported on EM copper grids subjected in air to the action of a single laser pulse $5 \mathrm{~ns}$ in width (FWHM) delivered from a photodissociation iodine laser $(\lambda \bumpeq 1.315 \mu \mathrm{m})$ at power density of $6.7 \times 10^{6}$. W. $\mathrm{cm}^{-2}$, are revealed by TEM and TED investigations.

\section{References}

[1] M.I.Bîrjega, R.M.Birjega, C.A.Constantin, M.Dinescu, I.Th.FIorescu, I.N.Mihäilescu, N.Popescu-Pogrion and C.Sârbu, Thin Solid Films, 145 (1986) 111 .

[2] I.Ursu, M.I.Bîrjegia, M.Dinescu, I.N.Mihăilescu, N.Popescu-Pogrion, C.A.Constantin; I. Ketskemety and E.Szill, MRS Proc. Vol. 74 (1986) 197.

[ӟ] I.Ursu, M.I.BÂrjega, C.A.Constantin, M.Dinescu, I.N.Mihăilescu, N.Popescu-Pogrion, I.Ketskemety and E.Szili, Supplement à la Revue Le Vide, Les Couches Minces 23.5 ( 1987 ) 573 .

[4] I.Ursu, M.I.Birjega, M.Dinescu, I.N.Mihăilescu, N.Popescu-Pogrion, L.Rîbco, I.Ketskemety, L.Nanai and E.Szill, Rev.Roum.Phys. 34 (1989) . I95.

[51 I.Ursu, M.I.Bîrjega, M.Dinescu, I.N.Mihăilescu, N.Popescu-Pogrion, L.Rîco, A.M. Prokhorov, V.I.Konov and V.N.Tokarev, Applied Surface science 36 ( 1989$)^{\prime} .640$.

[6] M.I.Birjega, C.A.Constantin, I.Th.Florescu and C.Sârbu, Thin Solid Films 92 (1982). 315 .

[7] C.Sârbu, S.A.Rău, N.Popescu-Pogrion and M.I.Birjega, Thin Solid Films 28 (1975). 311.

[8] L.Lassak and K.Hieber. Thin Solid Films 17 (1973). 105.

[9] M.I.Birjega and N.Popescu-Pogrion, Thin Solid Films 171 (1989) 33.

[10]R. Andrew, L.Baufay, A.Pigeolet and L.D.Laude, J. Appl. Phys. 53 (1982). 4862 .

[II]M.I.Bîrjega, C.A.Constantin, I.Th.Florescu, N.Popescu-Pogrion and C.Sârbu, Rev. Roum. Phys. 29 (I984) .219.

[12]A.M.Chaplanov and E.I.Tochitsky, Thin Solid Films 116 (1984) 117. 